Table 2 Duration and severity of colic: total hours with colic/No of symptomatic days (difficult colic in parentheses). The longest duration of each child is in bold

\begin{tabular}{|c|c|c|c|c|}
\hline \multirow{2}{*}{$\begin{array}{l}\text { Case } \\
\text { No }\end{array}$} & \multicolumn{4}{|l|}{ Milk feed } \\
\hline & Breast milk & $\begin{array}{l}\text { Breast milk } \\
\text { treated with } \\
\text { lactase }\end{array}$ & Formula & $\begin{array}{l}\text { Formula } \\
\text { treated with } \\
\text { lactase }\end{array}$ \\
\hline 1 & $0.6(0.2)$ & $3.4(3.2)$ & $5.2(1.6)$ & $1 \cdot 2(1 \cdot 0)$ \\
\hline 2 & $0.6(0)$ & $1.5(0)$ & $1.5(0)$ & $2.8(1.6)$ \\
\hline 3 & $0.5(0.5)$ & $0 \cdot 1(0)$ & $0.9(0.7)$ & $3.8(3.8)$ \\
\hline 4 & $8 \cdot 1(7 \cdot 3)$ & $4 \cdot 3(2 \cdot 5)$ & $6.9(3.3)$ & $17 \cdot 0(17 \cdot 0)$ \\
\hline 5 & $5.2(1.6)$ & $4.6(1.0)$ & $0.8(0.8)$ & $4.3(3.5)$ \\
\hline 6 & $0.2(0.2)$ & $0.2(0.2)$ & $0 \cdot 1(0 \cdot 1)$ & $0.4(0.3)$ \\
\hline 7 & $1.5(1.5)$ & $1 \cdot 1(1 \cdot 0)$ & $1 \cdot 0(0 \cdot 6)$ & $2 \cdot 2(2 \cdot 2)$ \\
\hline 8 & $0.7(0.6)$ & $2 \cdot 0(2 \cdot 0)$ & $2.9(2.9)$ & $1.8(0)$ \\
\hline 9 & $2.8(0.8)$ & $1.5(0.4)$ & $1.9(0.6)$ & $1 \cdot 2(0 \cdot 4)$ \\
\hline 10 & $5.5(5.5)$ & $2 \cdot 7(2 \cdot 2)$ & $1.2(0.9)$ & $3.5(3.3)$ \\
\hline
\end{tabular}

Two way analysis of variance: $F$ for overall colic $=1 \cdot 8, d f=3 / 27, p>0.05: F$ for difficult colic $=1.9 . \mathrm{df}=3 / 27, \mathrm{p}>0.05$.

Student's $t$ test: cow's milk formulas $v$ breast milks, $p>0.05$; lactose containing $v$ lactase treated milks, $\mathrm{p}>0.05$.

There were no differences between the milks in daily duration of colic (Table 2). Not even regrouping cow's milk formulas versus breast milks or lactose containing versus lactase treated milks showed any differences. Severity of attacks was also unaffected. In five children the total duration of colic and in six children the duration of difficult colic was, however, longest on cow's milk treated with lactase.

\section{Discussion}

The aetiology of infantile colic may be multiple, different causes operating in different children and perhaps one child's colic even being a result of several factors. To minimise the effects of confounding factors we conducted this investigation as a crossover study.

Colic was present on $89 \%$ of the days on cow's milk feeding and on $71 \%$ of the days on breast milk feeding. This difference was significant $(p<0 \cdot 05)$, but $71 \%$ is still high: colic is not cured by breast milk. No differences were found regarding severity of colic on those days when the disease was observed. Healthy infants may have physiologic lactase deficiency during several weeks, ${ }^{6}$ but infantile colic is not a symptom of lactose malabsorption. Other factors than milk must be crucial.

We are grateful to Valio Ltd for donation of formulas and treatment of milks with lactase.

\section{References}

1 Lothe L, Lindberg T, Jakobsson. I. Cow's milk formula as a cause of infantile colic: a double-blind study. Pediatrics 1982;70: 7-10.

2 Jakobsson I, Lindberg T. Cow's milk proteins cause infantile colic in breast-fed infants: a double-blind crossover study. Pediatrics 1983;71:268-71.

3 Evans RW, Fergusson DM, Allardyce RA, Taylor B. Maternal diet and infantile colic in breast-fed infants. Lancet $1981 ; \mathrm{i}$ : 1340-2.

${ }^{4}$ Ståhlberg M-R. Infantile colic: occurrence and risk factors. Eur J Pediatr 1984;143:108-11.

5 Liebman WM. Infantile colic, association with lactose and milk intolerance. JAMA 1981;245:732-3.

${ }^{6}$ Barr RG, Hanley J, Patterson DK, Wooldridge J. Breath hydrogen excretion in normal newborn infants in response to usual feeding patterns: evidence for "functional lactase insufficiency" beyond the first month of life. J Pediatr 1984;104: 527-33.

Correspondence to Dr M-R Ståhlberg, Department of Paediatrics, Turku University Hospital, SF-20520 Turku, Finland.

Received 7 August 1986

\title{
Somatomedin C deficiency in Asian sisters
}

\author{
M E MCGRAW, D A PRICE, AND D J HILL \\ Department of Child Health, Royal Manchester Children's Hospital, Manchester, and Department of \\ Paediatrics, University of Sheffield, Children's Hospital, Sheffield
}

\begin{abstract}
SUMmary Two sisters of Asian origin showed typical clinical and biochemical features of primary somatomedin C (SM-C) deficiency (Laron dwarfism). Abnormalities of SM-C binding proteins were observed, one sister lacking the high molecular weight $(150 \mathrm{Kd})$ protein.
\end{abstract}

In 1966 Laron et al first described a form of familial dwarfism characterised by the clinical features of severe growth hormone ( $\mathrm{hGH}$ ) deficiency and high concentrations of plasma immunoreactive hGH. ${ }^{1}$ Low plasma somatomedin activities before and during treatment with $\mathrm{hGH}$ indicate that the primary defect is in the production of somatomedin. ${ }^{2}$ Most reported cases of this autosomal recessive disorder are in oriental Jews, ${ }^{3}$ although a few patients of European origin have been described. ${ }^{2}$ We report two Asian sisters with Laron dwarfism 
and describe abnormalties of somatomedin C (SMC) binding proteins in their sera.

\section{Patients}

Case 1. This girl was born at term, weighing $2950 \mathrm{~g}$, with a length of $45.0 \mathrm{~cm}(-2.5$ standard deviation score (SDS)), to apparently non-consanguinous parents from Pakistan. The heights of both parents and three older male siblings were between the 25th and 50th centiles. She was 'jittery' shortly after birth, but hypoglycaemia was not confirmed. She grew poorly and at 2 years 3 months was referred to a paediatric endocrine unit. On examination her height was $67.5 \mathrm{~cm}(-5.6$ SDS), weight $7.46 \mathrm{~kg}$ ( -3.9 SDS), and triceps and subscapular skinfolds $>97$ centiles and she had typical somatic features of hyposomatotropism (Figure).

A full blood count, karyotype, tests of renal, hepatic, and thyroid function yielded normal results. Her bone age was 10 months. Serum prolactin concentrations rose from $112 \mathrm{mU} / \mathrm{l}$ to $1530 \mathrm{mU} / \mathrm{l}$ after intravenous thyrotrophin releasing hormone
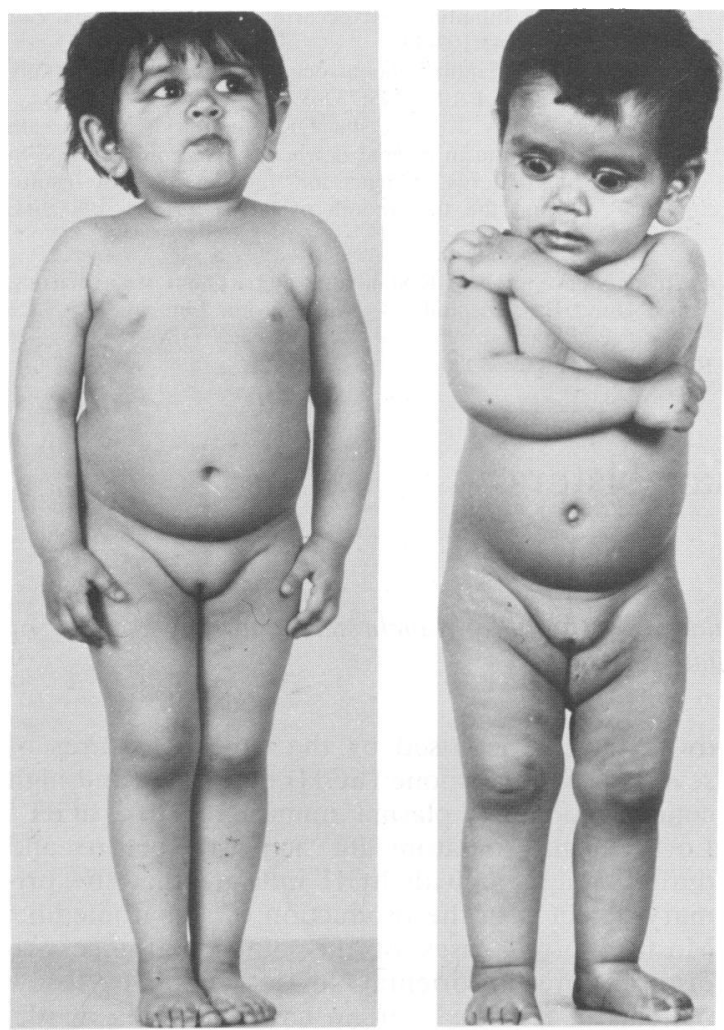

Figure Case 1 (left) and case 2 (right). stimulation. Serum hGH concentrations ranged from 65 to $150 \mathrm{mU} / \mathrm{l}$ (mean $108 \mathrm{mU} / \mathrm{l})$ during a 12 point 24 hour profile and from 54 to $100 \mathrm{mU} / \mathrm{l}$ (mean $80 \mathrm{mU} / \mathrm{l})$ in an arginine provocation test. Serum insulin concentrations were $<4 \mathrm{mU} / \mathrm{l}$ during arginine provocation.

Before treatment with $\mathrm{hGH}$, serum SM-C was $0.46 \mathrm{U} / \mathrm{ml}$, serum somatomedin activity 0.32 to 0.45 $\mathrm{U} / \mathrm{ml}$ during a 24 hour profile, and 24 hour urinary hydroxyproline/creatinine ratio 55; normal ranges at this age are $0.47-1.44 \mathrm{U} / \mathrm{ml}, 0.4-0.7 \mathrm{U} / \mathrm{ml}$, and 45-204, respectively.

Serum binding of $\left[{ }^{125} \mathrm{I}\right] \mathrm{Sm}-\mathrm{C}$ showed an absence of the specific $150 \mathrm{Kd}$ binding protein and the presence of binding to proteins ranging from $20 \mathrm{Kd}$ to $100 \mathrm{Kd}$, the greatest binding being of $40 \mathrm{Kd}$ to 60 Kd.

After two weeks of treatment with hGH (4 IU intramuscularly three times a week) there was no increase in serum SM-C $(0.2 \mathrm{U} / \mathrm{ml})$, serum somatomedin activity $(0 \cdot 33 \mathrm{U} / \mathrm{ml})$, and 24 hour urinary hydroxyproline/creatinine ratio (57). Despite a small increase in height velocity of $1 \mathrm{~cm} /$ year in the first month, this was not sustained over an eight month period.

Case 2. The sister of case 1 was born at 37 weeks' gestation with a weight of $3200 \mathrm{~g}$, but her length was not documented. She had asymptomatic hypoglycaemia and early feeding difficulties. At 1 year her height was $61.4 \mathrm{~cm}(-5 \cdot 1$ SDS), weight $6.1 \mathrm{~kg}(-3.8$ SDS), and triceps and subscapular skinfolds $>97$ th centiles and she had typical features of hyposomatotropism.

Her karyotype and thyroid function were normal. Serum prolactin concentrations rose from 346 to $1400 \mathrm{mU} / \mathrm{l}$ after intravenous thyrotrophin releasing hormone. Serum hGH concentrations ranged from 45 to $135 \mathrm{mU} / \mathrm{l}$ (mean $91 \mathrm{mU} / \mathrm{l})$ during a 12 point 24 hour profile and from 35 to $120 \mathrm{mU} / \mathrm{l}$ (mean 64 $\mathrm{mU} / \mathrm{l}$ ) during an arginine provocation test. Serum insulin concentrations were $<4 \mathrm{mU} / \mathrm{l}$ during arginine provocation. Basal serum SM-C concentrations ranged from 0.12 to $0.23 \mathrm{U} / \mathrm{ml}$ (mean $0.18 \mathrm{U} / \mathrm{ml}$ ) and basal serum somatomedin activity from 0 to 0.37 $\mathrm{U} / \mathrm{l}$ (mean $0 \cdot 16 \mathrm{U} / \mathrm{l})$.

Serum binding of [ $\left.{ }^{125} \mathrm{I}\right] \mathrm{SM}-\mathrm{C}$ showed the presence of the specific $150 \mathrm{Kd}$ binding protein and small amounts of binding activity at higher and lower molecular weights, especially in the $40-60 \mathrm{Kd}$ region.

\section{Methods}

hGH was measured by double antibody radioimmunoassay and somatomedin biological activity by 
the porcine costal cartilage bioassay. SM-C was measured by radioimmunoassay as previously described $^{4}$ after the removal of somatomedin binding proteins by extraction with acid-ethanol. The somatomedin binding proteins themselves were detected by their competition with activated charcoal for [ $\left.{ }^{125} \mathrm{I}\right] \mathrm{SM}-\mathrm{C}$, as previously described, ${ }^{4}$ after the fractionation of serum on Sephadex G200 eluted with $0 \cdot 05 \mathrm{M}$ phosphate buffer.

\section{Discussion}

The clinical and biochemical features of these two sisters strongly support the diagnosis of primary somatomedin deficiency, which was confirmed by failure of response to treatment with hGH in the older child. hGH injections did not produce somatomedin generation, although the small increase in height velocity, which has also been reported in other cases, ${ }^{12}$ led us to continue the therapeutic trial for eight months. It was not considered appropriate to offer treatment to the younger sister.

Circulating SM-C (insulin like growth factor 1), with its binding proteins, may predominantly reflect paracrine activity in growing tissues, have a true endocrine role, or represent the sum of paracrine and endocrine activity. SM-C is known to be hGH dependent in normal individuals, however, and is characteristically deficient in Laron dwarfism, despite high concentrations of endogenous hGH or treatment with exogenous hGH. SM-C does not exist in a free form in the plasma but is bound to proteins of various molecular weights, including a specific large molecular weight carrier protein (150 $\mathrm{Kd})$ that is itself hGH dependent and may be a hexamer of subunits of $24 \mathrm{Kd} .{ }^{5}$ An additional $40 \mathrm{Kd}$ binding species is present in various body fluids but is not dependent on growth hormone. The $150 \mathrm{Kd}$ protein was absent in the older sister but present in the younger. İt has been suggested that Laron dwarfism is due to defective hGh receptors; ${ }^{6}$ thus heterogeneity of production of the hGH dependent $150 \mathrm{Kd}$ protein is puzzling and may reflect quantita- tive differences of receptor number. This warrants further study.

The occurrence of Laron dwarfism in an Asian family should alert clinicians to consider the possibility in other Asian children with extreme short stature, relative adiposity, and high circulating hGH concentrations. Other features may include shortness at birth, neonatal hypoglycaemia, and a characteristic and appealing 'babyish' face with small central facial structures, relatively large calvarium, and occasionally a 'surprised appearance' due to slight proptosis. Hypogenitalism is noticeable in boys with this disorder. The condition is rare and is more likely to occur in a population with a high degree of consanguinity. It is hoped that in the future a trial of SM-C treatment may be of benefit.

We thank Mrs Sheena Wallace (technical help), Mrs K Cordwell, and the Salford Department of Medical Illustration.

[ ${ }^{125}$ I]SM-C and SM-C antibody (AS6) were kindly provided by Drs J J Van Wyk and L E Underwood, University of North Carolina, through the National Institute of Arthritis, Diabetes, and Digestive and Kidney Diseases.

\section{References}

' Laron Z, Pertzelan A, Mannheimer S. Genetic pituitary dwarfism with a high serum concentration of growth hormone, a new inborn error of metabolism? Isr J Med Sci 1966;2:152-5.

2 Van den Brande JL, Du Caju MVL, Visser HKA, et al. Primary somatomedin deficiency. Arch Dis Child 1974;49:297-304.

${ }^{3}$ Pertzelan A, Adam A, Laron Z. Genetic aspects of pituitary dwarfism due to absence of biological inactivity of growth hormone. Isr J Med Sci 1968;4:895-900.

4 Hill DJ, Crace CJ, Fowler L, et al. Cultured fetal rat myoblasts release peptide growth factors which are immunologically and biologically similar to somatomedin. J Cell Physiol 1984; 119:349-58.

5 Wilkins JR, d'Ercole AJ. Affinity labelled plasma somatomedin C/insulin like growth factor I binding proteins: evidence for growth hormone dependence and subunit structure. J Clin Invest 1985;75:1350-8.

6 Eshet R, Laron Z, Pertzelan A, et al. Defect of human growth hormone receptors in the liver of 2 patients with Laron-type dwarfism. Isr J Med Sci 1984;20:8-11.

Correspondence to Dr D A Price, Royal Manchester Children's Hospital, Pendlebury, Manchester M27 1HA, England.

Received 13 August 1986 